\title{
The effect of L-carnitine in Tris egg yolk-based diluent on the quality of Pasundan bull semen preserved in chilled condition
}

\author{
I. Darussalam ${ }^{1}$, R. I. Arifiantini' ${ }^{2, *}$, I. Supriatna' ${ }^{2}$ and R. S. D. $\operatorname{Rasad}^{3}$ \\ ${ }^{1}$ Reproductive Biology Program, Graduate School of IPB University, \\ Jl. Agatis, Dramaga Campus, Bogor 16680 - Indonesia. \\ ${ }^{2}$ Division of Reproduction and Obstetrics, Department of Veterinary Clinic, \\ Reproduction and Pathlogy, Faculty of Veterinary Medicine, IPB University, \\ Jl. Agatis, Dramaga Campus, Bogor 16680 - Indonesia. \\ ${ }^{3}$ Laboratory of Animal Reproduction and Artificial Insemination, \\ Faculty of Animal Husbandry, Padjadjaran University Jl Raya Bandung-Sumedang, \\ Jatinangor Campus, Sumedang 45363 - Indonesia. \\ *Correponding E-mail: iis.arifiantinipurna@gmail.com
}

Received March 26, 2020; Accepted June 16, 2020

\begin{abstract}
ABSTRAK
Penelitian ini dilakukan untuk mengevaluasi suplementasi L-Carnitine dalam pengencer Tris Kuning Telur (TKT) untuk mengoptimalkan kualitas semen cair sapi Pasundan. Semen dikoleksi dari tiga ekor sapi Pasundan (6 - 7 tahun) menggunakan vagina buatan. Semen dievaluasi secara makroskopis dan mikroskopis, semen yang memiliki $\geq 70 \%$ motilitas progresif, konsentrasi sperma $\geq 500$ $\times 10^{6} \mathrm{ml}^{-1}$, dan $\leq 20 \%$ sperma yang abnormal, dibagi menjadi lima bagian. Masing-masing diencerkan dengan TKT dan ditambah dengan $0 \mathrm{mM}$ (kontrol), $1 \mathrm{mM}, 2 \mathrm{mM}, 3 \mathrm{mM}$ dan $4 \mathrm{mM}$ L-Carnitine. Semen cair disimpan pada suhu $5{ }^{\circ} \mathrm{C}$. Motilitas sperma dievaluasi secara objektif menggunakan Computer Asissted Sperm Analysis (CASA) setiap 12 jam sampai motilitas progresif mencapai 40\%. Pengencer terbaik ditunjukkan oleh motilitas progresif (PM) pada pengencer TKT yang disuplementasi $1 \mathrm{mM} \mathrm{L}-$ Carnitine, hingga jam ke-108 (43,08 $\pm 0,49 \%)$ dibandingkan dengan kelompok kontrol $(43,63 \pm 0,70 \%)$ hanya sampai 72 jam $(\mathrm{P}<0,05)$. Kesimpulan penelitian ini adalah $1 \mathrm{mM}$ L-Carnitine dalam pengencer TKT merupakan konsentrasi terbaik untuk penyimpanan semen cair sapi Pasundan .
\end{abstract}

Kata kunci : L-Carnitine, semen cair, sapi Pasundan, pengencer kuning telur Tris

\begin{abstract}
The study was conducted to investigate the effect of L-Carnitine supplementation in Tris-egg yolk (TEY) diluents to optimize the quality of Pasundan bull liquid semen. Semen samples were collected from three Pasundan bulls ( $6-7$ years old) using an artificial vagina. Semen samples were evaluated macroscopically and microscopically, semen having $\geq 70 \%$ progressive motility, $\geq 500 \times 10^{6} \mathrm{ml}^{-1}$ sperm concentration and $\leq 20 \%$ sperm abnormalities were divided into 5 equal part. Each part was diluted with TEY and supplemented with $0 \mathrm{mM}$ (control), $1 \mathrm{mM}, 2 \mathrm{mM}, 3 \mathrm{mM}$ and $4 \mathrm{mM}$ L-Carnitine. Liquid semen was stored at $5{ }^{\circ} \mathrm{C}$. Sperm motility was evaluated every $12 \mathrm{~h}$ objectively using Computer Asissted Sperm Analysis (CASA) until progressive motility reached $40 \%$. The best diluent was demonstrated by progressive motility (PM) by TEY supplemented with $1 \mathrm{mM}$ L-Carnitine $(43.08 \pm 0.49 \%)$ that remained up to $108 \mathrm{~h}$ compared to the control group $(43.63 \pm 0.70 \%)$ that remained up to $72 \mathrm{~h}(\mathrm{P}<0.05)$. In conclusion, $1 \mathrm{mM}$ L-Carnitine in TEY was the best concentration for
\end{abstract}


preservation of Pasundan bull semen stored in the liquid form.

Keywords: L-Carnitine, liquid semen, Pasundan bulls, Tris-egg yolk diluents

\section{INTRODUCTION}

Pasundan cattle is one of the Indonesian local breeds. Population of Pasundan cattle at 2013 is estimated about 50.000 heads and mostly maintained by communities (cattle farmers) living along the northern and southern coastal areas of West Java with intensive and semi-extensive systems (Dwitresnadi et al., 2015). As local genetic resources, population of Pasundan cattle needs to be improved and conserved continuously. The current breeding program to improve Pasundan cattle is using artificial insemination (AI) technique with the use of frozen or liquid semen.

The use of frozen semen for AI in cattle is very common, however, liquid semen can be applied as an alternative method when the availability of liquid nitrogen is limited (Arifiantini and Purwantara, 2010). Liquid semen can minimize the metabolism of sperm. The condition of sperm during storage process will be exposed to reactive oxygen species (ROS). ROS play a pivotal role on several sperm functions through activation of different intracellular mechanisms such as sperm capacitation associated-events (Martin-Hidalgo et al., 2019). Therefore, sperm motility and viability in liquid semen maintained not over a long time (Fattah et al., 2017a).

The quality of liquid semen is affected by various factors including storage techniques and the type of diluents. Tris-egg yolk (TEY) is one of diluents commonly used in bull semen. TEY contains Tris-based material which is functioning as a buffer solution, fructose as an energy source and egg yolk containing phospholipid and lecithin to protect sperm from cold shock during cooling or freezing process. However liquid storage or the freeze-thawing process also produced the formation of ROS, such as $\mathrm{H}_{2} \mathrm{O}_{2}$ which results in damage to the sperm motility, viability and DNA integrity (Sariozkan et al., 2012; Perumal et al., 2013). Therefore, it is necessary to add an additive to the diluents in order to protect the sperm during cool-storage.

L-Carnitine (3-hydroxy-4-trimethylaminobutyrate) is a quaternary ammonium compound (Bieber, 1988) and water-soluble amino acid naturally biosynthesized in the kidney and liver of animal from lysine and methionine (Bremer, 1983). It plays a key role in reducing the availability of lipids for peroxidation by facilitating fatty acids transport into mitochondria for $\beta$-oxidation to generate Adenosine Triphosphate (ATP) energy (Neuman et al., 2002). Therefore, adding L-Carnitine in diluents medium will increase sperm motility (Agarwal and Said, 2004). L-Carnitine is found in seminal plasma and has a positive correlation with the quality of stallion semen (Stradaioli et al., 2004) and humans (Ahmed et al., 2011).

Antioxidant characteristics and antiapoptotic activity in L-Carnitine are able to stabilize the mitochondrial membrane and prevent damage to the DNA structure (Deon et al., 2015). L-Carnitine increases the activity and level of antioxidant enzymes such as catalase (CAT) and glutathione peroxidase (GPO) as well (Koberska and Yermishev, 2017). These enzymes play an important role in preventing oxidative damage (Bucak et al., 2010). The use of L-Carnitine in semen diluents have shown its beneficial effects on maintaining the quality of frozen semen in human (Banihani et al., 2014), chicken (Tabatabaei and Aghaei, 2012; Fatah et al., 2017a), cat (Manee-in et al., 2014), stallion (Gibb et al., 2015), sheep (Souza et al., 2019), buffalo (Longobardi et al., 2017) and bull (Bucak et al., 2010). However, the effects of addition of LCarnitine to semen diluents on the quality of liquid stored of bulls semen have not yet been investigated. Therefore, this study was conducted to investigate the efficacy of different L-Carnitine concentrations in the TEY diluents to improve the quality of Pasundan bulls semen stored in liquid form.

\section{MATERIAL AND METHODS}

\section{Animals}

Semen were obtained from three mature Pasundan bulls maintained at Beef Cattle Breeding Development Center and Artificial Insemination Institute, Cijeungjing, Ciamis., West Java, Indonesia. Age of the bulls was between 6 to 7 years with body weight of 380 to $430 \mathrm{~kg}$. Bulls were managed in similar fed of Pennisetum purpureum grass up to $10 \%$ of body weight and commercial concentrate up to $1 \%$ of body weight 
containing $16 \%$ crude protein. Fed is given twice a day and water is given ad libitum. Approval for the current study was given by the Animal Care and Use Committee (ACUC) at IPB University No. 143 - 2019 IPB.

\section{Chemicals}

All chemicals used in this research were purchased from Merck (Darmstadt, Germany) unless it was stated.

\section{Preparation of diluents}

The basic diluents used for this study is Trisegg yolk (TEY). Tris buffer consists of $3.03 \mathrm{~g}$ Tris (hydroxymethyl) aminomethane, $1.78 \mathrm{~g}$ citric acid, $1.25 \mathrm{~g}$ fructose in $100 \mathrm{ml}$ of aquabidest. Trisegg yolk consisted of $80 \%$ Tris buffer and $20 \%$ of egg yolk, well mixed and centrifuged at $3000 \mathrm{rpm}$ for 10 minutes, the supernatant was taken as a diluents. The TEY diluent was divided into five equal part and each part was supplemented with different concentrations of L-Carnitine (Sigma, Cat no: C0158), 0 (control) 1, 2, 3, and $4 \mathrm{mM}$ (Table 1).

\section{Semen Collection and Evaluation}

The ejaculates from each bull were collected using an artificial vagina once a week, in the morning at $07.30 \mathrm{AM}$ to $10.00 \mathrm{AM}$ according to the Operational Standard Procedure of the AI centre. Immediately after collection, semen samples were evaluated both macroscopically and microscopically according to Arifiantini (2012). Macroscopic evaluation includes volume, color, $\mathrm{pH}$ and consistency. Volume $(\mathrm{ml})$ was determined from the scale of graduated conical test tube attached to the artificial vagina. Color and consistency were determined visually and $\mathrm{pH}$ was measured by indicator paper (Merck, scale 6.4-8, 0.2 sensitivity).

Microscopic evaluation includes mass activity, sperm progressive motility, sperm viability, sperm morphology and sperm concentration. Mass activity was evaluated by dropping $10 \mu \mathrm{l}$ of semen on warm object glass and evaluated under light microscope (Olympus CX23) at $100 \times$ magnification. Evaluation of sperm motility was conducted by mixing $10 \mu \mathrm{l}$ of semen with $40 \mu$ of saline solution on a clean glass object then examined objectively using Computer Asissted Sperm Analysis (CASA; Androvision, Germany).

The percentages of sperm viability and morphology were evaluated with the same slide using eosin-nigrosin staining technique. Ten microlitre of semen and $40 \mu \mathrm{l}$ of eosin-nigrosin were placed on a clean glass object, homogenized, smeared, and dried above heating table. Sperm concentration was evaluated using a photometer (SDM 6, Minitub, Germany). Semen that having $\geq 70 \%$ progressive motility of sperm, concentration of sperm $\geq 500 \times 10^{6} \mathrm{ml}^{-1}$ and morphologically abnormal sperm $\leq 20 \%$ were used for the experiment.

\section{Processing of Liquid Semen}

Fresh semen that match with criteria that used for this experiment were diluted based on the treatment (Table 1). The final sperm concentration was approximately $10 \times 10^{6}$ sperm $\mathrm{ml}^{-1}$. The diluted semen was then packaged in a corning tube $(15 \mathrm{ml})$. The samples were then placed in a beaker glass with water jacket and cooled from 37 ${ }^{\circ} \mathrm{C}$ to $5{ }^{\circ} \mathrm{C}$ and then stored at $5{ }^{\circ} \mathrm{C}$ (Arifiantini and Purwantara, 2010).

\section{Evaluation of Sperm Parameters during Chilled-storage}

Sperm Motility. Twenty $\mu$ of semen was dropped on the warm object glass and then covered using a cover slip. Samples were then placed in heating table for thirty second and then observed in seven visual fields with 200× magnification. Liquid semen were evaluated every 12 hour. The variables tested were sperm motility for total motility (TM) and progressive motility (PM). The movement speed of the sperm were divided into fast motility (FM), slow motility (SM), local motility (LM) and immotile (IM). The evaluation were done until the sperm PM values reach $40 \%$.

Sperm Viability. Twenty $\mu$ l of semen with $40 \mu \mathrm{l}$ of eosin-nigrosin solution were homogenized, smeared, and dried above heating plate. The stained slide was evaluated using a light microscope at $400 \times$ magnification and at least 200 sperm cells were counted in ten different microscopic fields (Arifiantini and Yusuf, 2010). Sperms which did not take up the eosin-nigrosin stain were considered alive, while those that did take up the stain were considered dead. Value is expressed in percentage (\%). 
Table 1. Composition of Tris Egg Yolk-Based Diluents

\begin{tabular}{lccccc}
\hline \multicolumn{1}{c}{ Ingredients } & \multicolumn{5}{c}{ Total of Additions } \\
\hline Tris buffer $(\mathrm{mL})$ & 80 & 80 & 80 & 80 & 80 \\
Egg yolk $(\mathrm{mL}) *$ & 20 & 20 & 20 & 20 & 20 \\
L-Carnitine $(\mathrm{mM})$ & 0 & 1 & 2 & 3 & 4 \\
Penicilline $(\mathrm{IU} / \mathrm{mL})^{* *}$ & 1000 & 1000 & 1000 & 1000 & 1000 \\
Streptomycine $(\mathrm{mg} / \mathrm{mL})^{* *}$ & 1 & 1 & 1 & 1 & 1 \\
\hline
\end{tabular}

*Fresh hen egg yolk

** Meiji Seika Pharma Co., Ltd, Japan

Table 2. Characteristics of Pasundan Bull Fresh Semen

\begin{tabular}{lc}
\hline \multicolumn{1}{c}{ Semen Characteristics } & Mean \pm SEM \\
\hline Volume $(\mathrm{ml})$ & $4.66 \pm 0.32$ \\
Colour & Milky white \\
$\mathrm{pH}$ & $6.44 \pm 0.02$ \\
Consistency & Moderate \\
Mass motility & ++ to +++ \\
Progressive motility $(\%)$ & $80.38 \pm 0.92$ \\
Sperm concentration & \\
$\left(\times 10^{6}\right.$ sperm ml $\left.^{-1}\right)$ & $1016.95 \pm 50.45$ \\
Sperm viability $(\%)$ & $81.17 \pm 1.62$ \\
Sperm abnormality $(\%)$ & $11.92 \pm 0.81$ \\
\hline
\end{tabular}

\section{Research Design and Data Analysis}

The study was designed using a completely randomized design (CRD) in time. Each treatment consists of four replications. Data were analyzed using analysis of variance (ANOVA) with SAS program version 9, followed by Duncan Multi Range Test if differences were found within and between treatments. Data are expressed as means \pm SEM.

\section{RESULTS}

\section{Quality of Pasundan Bull Fresh Semen}

The results demonstrated macroscopically Pasundan bulls semen shows a volume of $4.66 \pm$ $0.32 \mathrm{ml}$, milky white in colour, $\mathrm{pH}$ of $6.44 \pm 0.02$ with moderate consistency. Microscopic evaluation showed mass movement of ++ to +++ , progressive motility $80.38 \pm 0.92 \%$ with sperm concentration of $1016.95 \pm 50.45 \times 10^{6} \mathrm{ml}^{-1}$. Sperm viability and abnormalities value, in this study were $81.17 \pm 1.62 \%$ and $11.92 \pm 0.81 \%$, respectively (Table 2).

\section{Effect of Various L-Carnitine Concentration in Tris-egg Yolk Diluents on the Motility Parameters of Pasundan Bulls Sperm}

The computer-assisted sperm analysis demonstrated a decrease in TM and PM of Pasundan bulls sperm during storage. The decrease in TM did not quick as decrease in PM (Figure 1a and Figure 1b), and only after $84 \mathrm{~h}$ of storage we can see the effect of L-Carnitine. At 84 $\mathrm{h}$ of storage the TM of sperm without addition of L-Carnitine $(88.19 \pm 0.30 \%)$ was lower $(\mathrm{P}<0.05)$ than that of TM of sperm supplemented with LCarnitine 1, 2, 3 and $4 \mathrm{mM}$ that is $91.99 \pm 0.25 \%$, $90.98 \pm 0.37 \%, 91.24 \pm 0.79 \%, 90.54 \pm 0.67 \%$, respectively. At $108 \mathrm{~h}$ of storage, TM of sperm in TEY diluent with the addition of $1 \mathrm{mM} \mathrm{L-}$ Carnitine ( $89.64 \pm 0.15 \%)$ was found to be higher $(\mathrm{P}<0.05)$ than that of TM of sperm the addition of $2 \mathrm{mM}$ and $3 \mathrm{mM}$ L-Carnitine $(88.60 \pm 0.49 \%$ and $88.64 \pm 0.74 \%$, respectively; Figure 1a). Thereafter, when time of storage reached $120 \mathrm{~h}$, only TM of sperm in diluent with $1 \mathrm{mM} \mathrm{L}$ Carnitine remained high $(87.83 \pm 0.47 \%)$.

In contrast with TM, the value of PM sperm in TEY diluents decreased gradually as storage time increase from 0 to $84 \mathrm{~h}$. the value of PM sperm in TEY diluents given with $1 \mathrm{mM} \mathrm{L-}$ Carnitine reached a value of $49.44 \pm 0.92 \%$ at 84 $\mathrm{h}$ of storage, this was higher $(\mathrm{P}<0.05)$ than sperm in TEY diluents given with 0 (control), 2, 3 and 4 $\mathrm{mM}$ L-Carnitine showed the value of $39.40 \pm$ $0.49 \%, 46.11 \pm 0.67 \%, 44.27 \pm 1.24 \%, 44.13 \pm$ 
$0.55 \%$ respectively. Afterward, when time of storage reached $120 \mathrm{~h}$, only PM of sperm in diluent with $1 \mathrm{mM}$ L-Carnitine remained high (Figure 1b).

No differences were found in FM of sperm at $84 \mathrm{~h}$ of storage in TEY diluents with different LCarnitine concentration (Figure 2a). The FM were between $5.85 \pm 1.02 \%$ to $6.82 \pm 0.72 \%$ higher $(\mathrm{P}<0.05)$ than control $(3.64 \pm 0.20 \%)$. The speed of sperm with SM, LM and IM category in TEY with $1 \mathrm{mM}$ L-Carnitine have similar pattern with

$1 \mathrm{a}$.

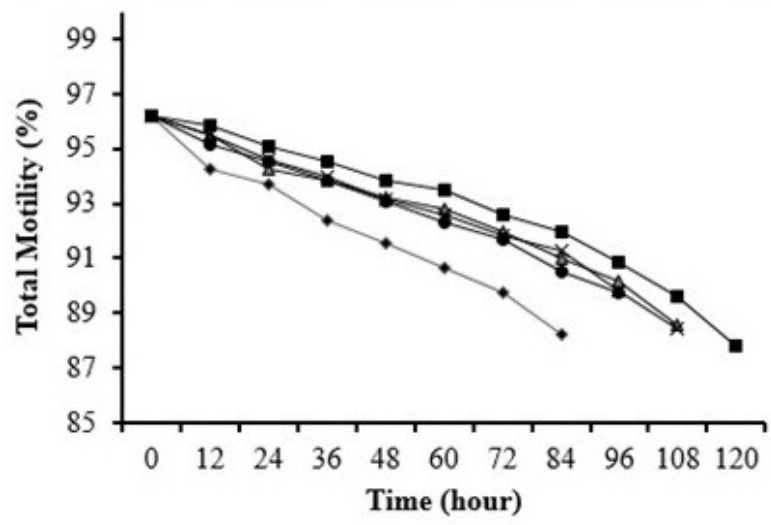

PM category that was significantly at $84 \mathrm{~h}$ of storage (Figure 2b, Figure 3a and Figure 3b). It was clear from the data that addition $1 \mathrm{mM}$ LCarnitine in TEY diluents give the best result for sperm motility parameter.

\section{Effect of Various L-Carnitine Concentration in Tris-egg Yolk Diluents on the Viability of Pasundan bulls sperm}

Viability of Pasundan bull sperm in this study shows a similar trend to PM of sperm.

$1 \mathrm{~b}$.

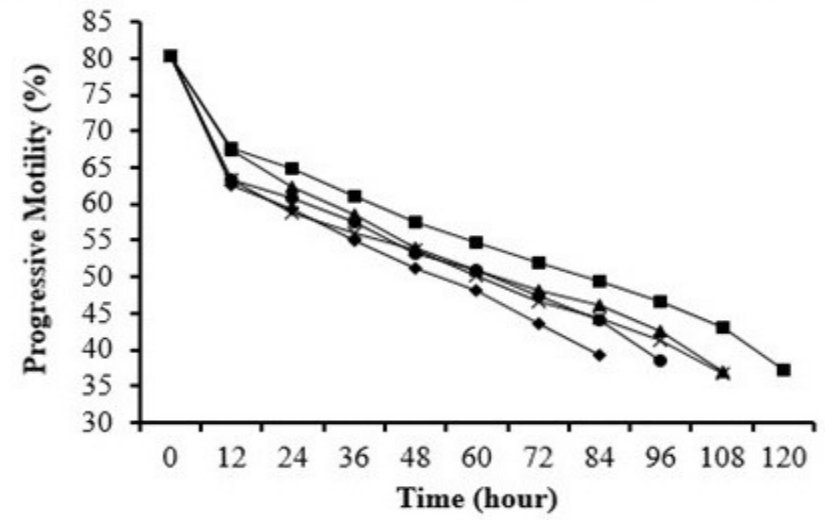

Figure 1. Total motility (TM) and progressive motility (PM) of Pasundan bull sperm in Tris-egg yolk diluents with a various concentrations of L-Carnitine (LC). The symbol represent diluents with $0 \mathrm{mM}$

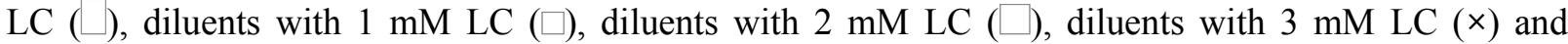
diluents with $4 \mathrm{mM} \mathrm{LC}(\square)$.

$2 \mathrm{a}$.

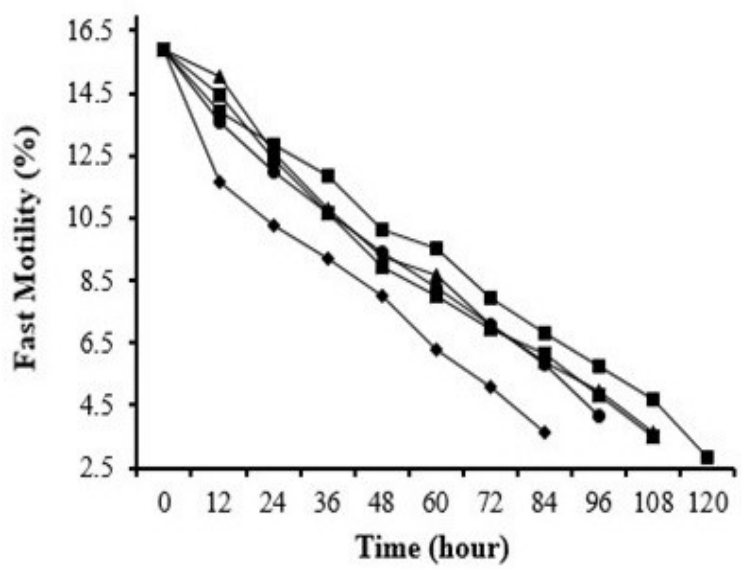

$2 b$.

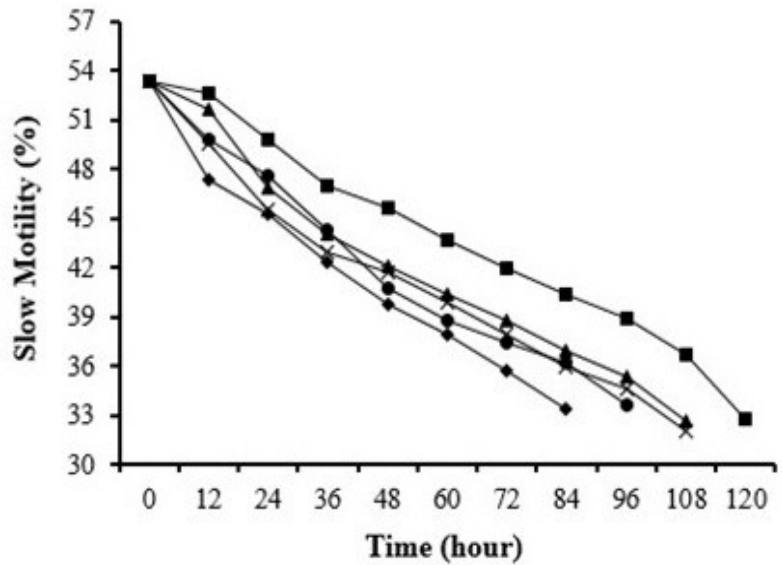

Figure 2. Fast motility (FM) and slow motility (SM) of Pasundan bull sperm in Tris-egg yolk diluents with a various concentrations of L-Carnitine (LC). The symbol represent diluents with $0 \mathrm{mM} \mathrm{LC} \mathrm{( \square ),}$

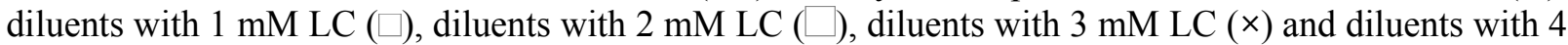
$\mathrm{mM} \mathrm{LC}(\square)$ 
$3 a$.

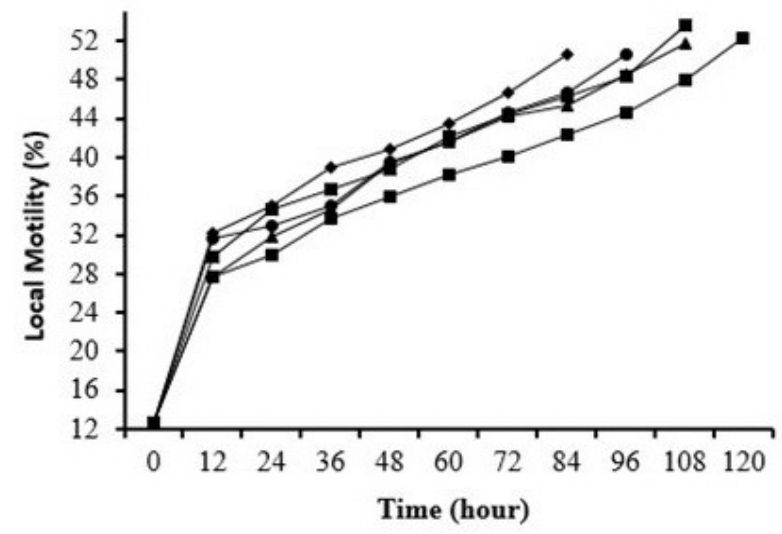

$3 b$.

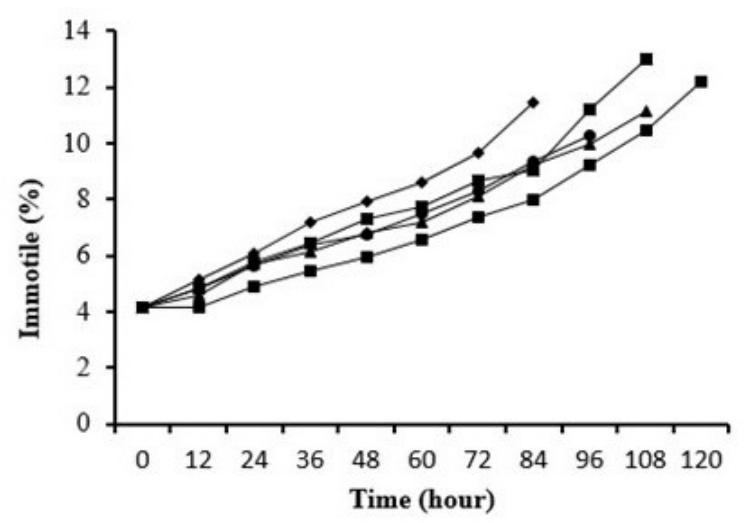

Figure 3. Local motility (LM) and Immotile (IM) of Pasundan bull sperm in Tris-egg yolk diluents with

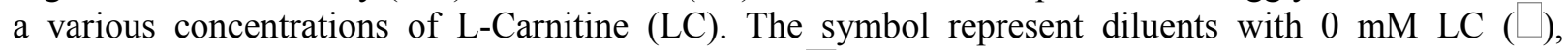

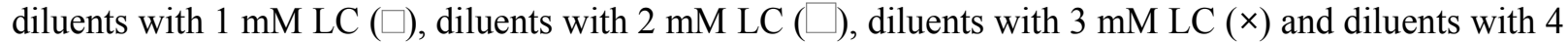
$\mathrm{mM} \mathrm{LC}(\square)$.

Viability of sperm in TEY with $1 \mathrm{mM}$ L-Carnitine showed the best concentration. A value of $43.95 \pm$ $0.42 \%$ was shown at $108 \mathrm{~h}$ of storage, while given with L-Carnitine 2, 3 and 4, the same value was only up to $96 \mathrm{~h}$, even the control was only up to $84 \mathrm{~h}$ (Figure 4).

\section{DISSCUSION}

The value of the semen volume of Pasundan bulls was higher than that of Baharun et al. (2017) who recorded volume of $3.80 \pm 0.58 \mathrm{ml}$ collected from the same bulls. The volume of Pasundan bulls semen is still in the normal range, according to Arifiantini (2012) the volume of bulls semen ranges from $2-15 \mathrm{ml}$. The semen colour is still normal according to Garner and Hafez (2000) that observed the colour of normal ejaculate of bull semen is creamy to milky white. The semen $\mathrm{pH}$ is still normal according to Arifiantini (2012) normal range semen of mammals from 6.0-7.5.

Microscopic evaluation showed that the motility value of sperm was lower when compared with Baharun et al. (2017), that showed the motility value of $82.41 \pm 2.97 \%$ in the same type of bulls. The sperm concentration in this study was slightly lower than Baharun et al. (2017) in Pasundan bulls, that was $1355.85 \pm$ $6.06 \times 10^{6} \mathrm{~m}^{-1}$. The sperm concentration in this study was still in the normal range according to Garner and Hafez (2000). Normal sperm

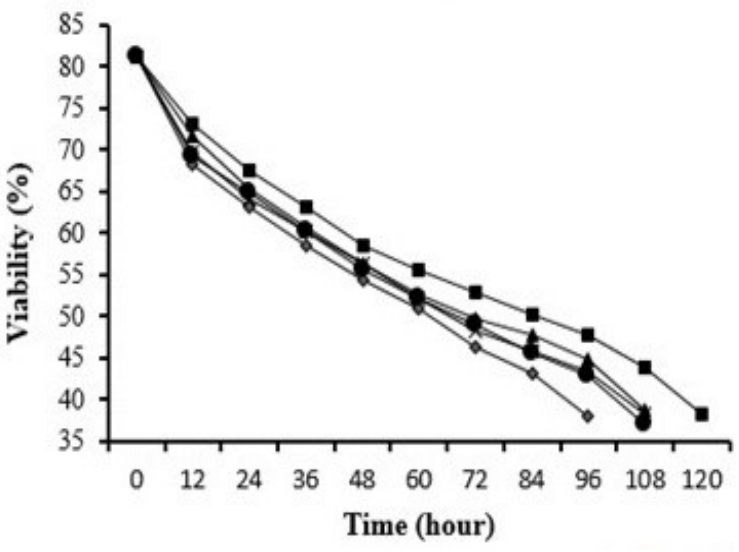

Figure 4. Viability of Pasundan bull sperm in Tris-egg yolk diluents with a various concentrations of L-Carnitine (LC). The symbol

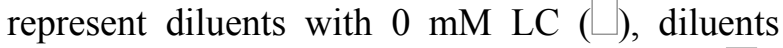

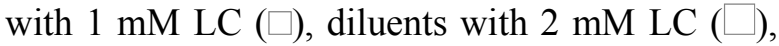
diluents with $3 \mathrm{mM} \mathrm{LC} \mathrm{( \times )}$ and diluents with 4 mM LC ( $\square$ ).

concentration in bulls ranges from $800-2000 \times 10^{6}$ sperm $\mathrm{ml}^{-1}$. Sperm viability and abnormalities, obtained in this study almost the same value as Baharun et al. (2017) that indicate the viability and abnormalities of $84.37 \pm 1.05 \%$ and $11.13 \pm$ $0.39 \%$ respectively. The quality of fresh semen from this study qualifies to be processed as liquid semen. 
Under physiological conditions, sperm produce small amounts of ROS, which are needed for capacitation and acrosomal reaction (Agarwal et al., 2003). Since mammalian sperm plasma membrane and cytoplasm contain large amounts of polyunsaturated fatty acids; are vulnerable to excessive amount of ROS that produced from dead, abnormal sperm cell as well as leukocytes content (Agarwal and Prabakaran, 2005). The longer periods of storage, sperm may lead to an increased level of dismutation of the superoxide anion generating higher levels of oxidative stress within the sperm sample (de Lamirande and O'Flaherty, 2008). As expected, the TM and PM score on all treatments declined with respect to time. However, semen supplemented with $1 \mathrm{mM}$ of L-Carnitine retained a PM score of at least $40 \%$ up to $\mathrm{h} 84$ of the study.

In this study, the addition of L-Carnitine proved to be better than controls. Concentration of $1 \mathrm{mM}$ L-Carnitine in TEY diluents showed the best effect in all variables. The high PM in TEY diluents supplemented by L-Carnitine is related to the function of L-Carnitine which can increase mitochondrial activity (Fattah et al., 2017a). The mitochondria contained in the middle part of the sperm was responsible to produce ATP which is used for the sperm movement.

The addition of $1 \mathrm{mM} \mathrm{L-Carnitine} \mathrm{also}$ proved to be better than controls in of motile sperm (Figure 2a and $b$ ). Figure $3 a$ and $b$ (local and immotile sperm) in liquid semen added with 1 $\mathrm{mM}$ L-Carnitine demonstrated lower value than control or other concentration of L-Carnitine. This is related with the functions of L-Carnitine to facilitate the transport of fatty acids to the mitochondrial membrane to produce ATP through the process of $\beta$-oxidation so it can increase sperm motility (Agarwal and Said, 2004). Supplementation of L-Carnitine in liquid stored diluents according to Longobardi et al. (2017) can increase ATP production by up to twice when compared to controls. Supplementation of LCarnitine in the diluents leads to a partial removal of $\mathrm{Na}$ from diluents (Gibb et al., 2015) to maintain isotonicity (Silver and Erecinska, 1997). $\mathrm{Na}$ increases the depletion of ATP via activation of Na-ATPase pumps (Silver and Erecinska, 1997).

The research on addition of L-Carnitine in bull liquid semen has never been reported. The addition of L-Carnitine to liquid semen was only reported in rooster semen (Tabatabaei and Aghaei, 2012; Fatah et al., 2017a), rabbit (Sariozkans et al., 2014) and horses (Gibb et al., 2015). All researchers conclude that the addition of LCarnitine to liquid semen can improve the quality of semen during preservation.

This research had found that adding of LCarnitine ( $1 \mathrm{mM})$ to Pasundan bull semen diluent can enhance its sperm viability $43.95 \pm 0.42 \%$ until $108 \mathrm{~h}$ by looking through Figure 4. LCarnitine as anti-oxidant (Solarska et al., 2010), may protect sperm plasma membrane with high level of unsaturated fatty acid content (Aitken et al., 2010). The process of liquid semen causes the formation of ROS. ROS can induced the lipid peroxidation due to mammalian sperm membrane has high polyunsaturated fatty acids, thus resulted in the deterioration of sperm viability.

Antioxidant characteristics and antiapoptotic activities of L-Carnitine have a protective role against damaging effects of ROS and may stabilize mitochondrial membrane and DNA structure (Qi et al., 2006). L-Carnitine also increases the activity and levels of antioxidant enzymes such as superoxide dismutase and glutathione peroxidase (Neuman et al., 2002). LCarnitine arise from the scavenging of ROS, destroyed hydrogen peroxide and has a function on metal chelation as well as inhibition of xanthine oxidase activity by L-Carnitine (Surai, 2015).

The evidence of the decreasing in lipid peroxidation at $48 \mathrm{~h}$ of liquid semen testing with additional L-Carnitine by 1 and $2 \mathrm{mM}$ was reported by Fattah et al. (2017a). In addition, according to Longobardi et al. (2017), total antioxidant capacity (TAC) increases and ROS production decreases when L-Carnitine was added to the semen diluents. On the other hand, LCarnitine has a function to interact with membrane phospholipid, which modulates fluidity of plasma membrane (Fattah et al., 2017b). The decreasing of ROS and cell membrane can be maintained, this will cause the enhancement of sperm viability. This mechanism proved that it is matched with the result of our study that sperm viability that supplemented with L-Carnitine was better than control.

Tabatabaei and Aghaei (2012) reported that the sperm viability of chicken liquid semen given with L-Carnitine supplementation as much as $1 \%$ at $24 \mathrm{~h}$ showed significant results compared with L-Carnitine 2\% and 3\%. Fattah et al. (2017a), reported that $2 \mathrm{mM}$ L-Carnitine supplementation was the best results of chicken sperm viability at $48 \mathrm{~h}$ when compared with L-Carnitine 
concentrations of $0.5,1,4$ and $8 \mathrm{mM}$. The present study showed that $1 \mathrm{mM}$ of L-Carnitine supplementation demonstrated the best results, it was probably due to the differences in physiology between bulls and chicken sperm.

L-Carnitine plays an essential role in $\beta$ oxidation (Gib et al., 2015). Addition of LCarnitine to diluents act as antioxidant and osmolyte. L-Carnitine assisting mitochondrial ATP production through the transportation of acetyl groups from pyruvate into the mitochondrial matrix and the buffering of free coenzyme-A (CoA). Production of ATP, thus maintained sperm motility. In the other hand LCarnitine is powerful osmolyte (Fattah et al. 2017) and therefore in the present study its supplementation to diluents in higher concentrations of L-Carnitine (2, 3 and $4 \mathrm{mM}$ ) might related along with a high osmolality, and interrupt sperm plasma membrane thus decrease sperm motility.

\section{CONCLUSION}

The conclusion based on the best finding results demonstrated that the supplementation of L-Carnitine $(1 \mathrm{mM})$ in the diluents medium not only preserve the sperm cell motility parameters but also preserving its viability of Pasundan bull liquid semen. Further applied reserach should be conducted either in the field using AI and or in the laboratory using in vitro fertilization (IVF) test to determine that supplemented $1 \mathrm{mM}$ L-Carnitine in the diluents can enhanced the fertility.

\section{CONFLICT OF INTEREST}

There is no conflict of interest with any financial, personal, or other relationship with other people or organization related to the material discussed in the manuscript.

\section{ACKNOWLEDGEMENT}

This paper is supported by USAID Through Sustainable Higher Education Research Alliances (SHERA) Program-Center for Collaborative Research Animal Biotechnology and Coral Reef Fisheries (CCR ANBIOCORE). The authors thanks to Center of Beef Cattle Breeding Development and Artificial Insemination Institute Cijeungjing, Ciamis for facilitating the research materials and laboratory.

\section{REFERENCES}

Aitken, R.J., M.A., Baker, G.N. De Iuliis and B. Nixon . 2010. New insights into sperm physiology and pathology. Handb Exp. Pharmacol. 198:99-115

Agarwal, A. and T. M. Said. 2004. Carnitines and male infertility. Reprod Biomed Online. 8(4):376-384.

Agarwal, A. and S. A. Prabakaran. 2005. Oxidative stress and antioxidants in male infertility: a difficult balance. Iranian $\mathrm{J}$. Reprod Med. 3 (1): 1-8

Ahmed, S.D.H., K.A. Karira, Jagdesh, and S. Ahsan. 2011. Role of L-Carnitine in male infertility. J. Pak. Med. Assoc. 61(8):732736.

Arifiantini, R.I. and B. Purwantara. 2010. Motility and viability of friesian holstein spermatozoa in three different extender stored at $5{ }^{\circ} \mathrm{C}$. J. Indonesian Trop. Anim. Agric. 35(4): 222-226.

Arifiantini, R.I. and T.L. Yusuf. 2010. Developing of tris soy milk diluent for frisian holstein bull frozen semen. Hayati. J. Biosci. 17(2): 91-94.

Arifiantini, R.I. 2012. Technique of Semen Collection and Evaluation. IPB Press, Bogor.

Baharun, A., R. I. Arifiantini, and T. L. Yusuf. 2017. Freezing capability of pasundan bull sperm using tris-egg yolk tris-soy and andromed diluents. J. Ked. Hewan. 11(1): 45-49.

Banihani, S., A. Agarwal, R. Sharma, and M. Bayachou. 2014. Cryoprotective effect of LCarnitine on motility, vitality and DNA oxidation of human spermatozoa. Andrologia. 46(6): 637-41.

Bieber, L.L. 1988. Carnitine. Annu Rev Biochem. 57: 261-283.

Bremer, J., 1983. Carnitine metabolism and functions. Physiol Rev. 63(4): 1420-1480.

Bucak, M. N., P. B. Tuncer, S. Sariozkan, N. Baspinar, M. Taspinar, K. Coyan, A. Bilgili, P. B. Akalin, S. Buyukleblebici, S. Aydos, S. Ilgaz, A. Sunguroglu, and D. Oztuna. 2010. Effect of antioxidant on post-thawed bovine sperm and oxidative stress parameters: Antioxidant protect DNA integrity againts cryodamage. Cryobiol. 61(3):248-253.

Deon, M., S.S. Landgraf, J. F. Lamberty, D. J. Moura, J. Saffi, M. Wajner, and C.R. Vargas. 2015. Protective effect of L- 
Carnitine on Phenylalanine-induced DNA damage. Metab Brain Dis. 30(4):925-933.

de Lamirande, E., and C. O'Flaherty. 2008. Sperm activation: Role of reactive oxygen species and kinases. Biochim. Biophys. Acta 1784: 106-115

Dwitresnadi, R., M. Sulaeman, and J. Arifin. 2015. Breeding activity performance of Pasundan cattle on extensive system. J Fapet UNPAD. 4(3): 1-11.

Fattah, I., M. Sharafi, R. Masoudi. A. Shahverdi, and V. Esmaeili. 2017a. L-Carnitine is a survival factor for chilled semen storage of rooster for a long time. Cryobiology. 74: 13-18.

Fattah, I., M. Sharafi, R. Masoudi. A. Shahverdi, V. Esmaeili and A. Najavi. 2017b. LCarnitine in rooster semen cryopreservation: flow cytometric, biochemical and motion findings for frozenthawed sperm. Cryobiology. 74:148-153.

Garner, D.L. and E. S. E Hafez. 2000. Spermatozoa and seminal plasma. In: Hafez $\mathrm{B}$ and Hafez ESE (eds.), Reproduction in farm animals $7^{\text {th }}$ (Ed). pp. 96-109. Lippincott Williams and Wilkins. Philadelphia, USA.

Gibb, Z., S. R. Lambourne, J. Quadrelli, N. D. Smith, and R. J. Aitken. 2015. L-Carnitine and pyruvate are prosurvival factors during the storage of stallion spermatozoa at room temperature. Biol Reprod. 93(4): 1-9.

Koberska, V. and O. Yermishev. 2017. Intensity of oxygen consumption by bull sperm due to the action of L-Carnitine. Biologija. 63(4): 306-312.

Longobardi, V., A. Salzano, G. Campanile, R. Marrone, F. Palumbo, M. Vitiello, G. Zullo, and B. Gasparini. 2017. Carnitine supplementation decreases capacitation-like changes of frozen-thawed buffalo spermatozoa. Theriogenology. 88: 236-243.

Manee-in, S., S. Parmornsupornvichit, S. Kraiprayoon, T. Tharasanit, P. Chanapiwat, and K. Kaeoket. 2014. L-Carnitine supplemented extender improves cryopreserved-thawed cat epididymal sperm motility. Asian-Australas. J. Anim. Sci. 27(6):791-796.

Martin-Hidalgo, D., M.J. Bragado., A. R. Batista., P. F. Oliveira and M. G. Alves. 2019. Antioxidants and Male Fertility: From Molecular Studies to Clinical Evidence. Antioxidants. 8 (89): 1-21.
Neuman, S.L., T.L. Lin, and P.Y. Hester. 2002. The effect of dietary caritine on semen traits of white leghorn roosters. Poult. Sci. 81: 495-503.

Perumal, P., K. Vupru, and C. Rajkhowa. 2013. Effect of addition of taurine on the liquid storage $\left(5^{\circ} \mathrm{C}\right)$ of mithun (Bos frontalis) semen. Vet. Med. Article ID 165348.

Qi, S.N., Z.F. Zhang, Z.Y. Wang, A. Yoshida, and T. Ueda. 2006. L-Carnitine inhibits apoptotic dna fragmentation induced by a new spin-labeled derivative of podophyllotoxin via caspase- 3 in raji cells. Oncol. Rep. 15:119-122.

Sariozkan, S., M. N. Bucak, F. Canturk, S. Ozdamar, A. Yay, P. B. Tuncer, S. Ozcan, N. Sorgucu, and Y. Caner. 2012. The effect of different sugars on motility, morphology and DNA damage during the liquid storage of rat epididymal sperm $4{ }^{\circ} \mathrm{C}$. Cryobiology. 65(2):93-97.

Sariozkan, S., S. Ozdamar, G. Turk, F. Canturk, and A. Yay. 2014. In vitro effects of LCarnitine and glutamine on motility, acrosomal abnormality, and plasma membrane integrity of rabbit sperm during liquid-storage. Cryobiology. 68:349-353.

Silver, L.A. and M. Erecinska. 1997. Energetic demands of the $\mathrm{Na}+/ \mathrm{K}+$ ATPase in mammalian astrocytes. Glia. 21(1): 35-45.

Solarska, K., A. Lewińska, A. Karowicz-Bilińska and G. Bartosz. 2010. The antioxidant properties of carnitine in vitro. Cell Mol. Biol. Lett. 15:90-97

Souza, C.V., F.Z. Brandao, J.D.R. Santos, V.A.P. Alfradique, V.M.B. Santos, M.C.C. Morais, P.S.C. Rangel, A.A. Silva, and J.M.G.S. Fabjan. 2019. Effect of different concentrations of L-Carnitine in extender for semen cryopreservation in sheep. Cryobiology. 89:104-108.

Stradaioli, G., L. Sylla, R. Zelli, P. Chiodi, and M. Monaci. 2004. Effect of L-Carnitine administration on the seminal characteristics of oligoasthenospermic stallions. Theriogenology. 62: 761-777.

Surai, P. F. 2015. "Antioxidant Action of Carnitine: Molecular Mechanisms and Practical Applications". EC Vet. Sci. 2.1: 66-84

Tabatabaei, S., and A. Aghaei. 2012. Effect of LCarnitine on sperm quality during liquid storage of chicken semen. Comp. Clin. Pathol. 21: 711-717. 